\title{
The Effects of Aerobic Capacity Level on Biochemical Changes in Response to Anaerobic Exercise and During Post-Exercise Recovery in Football Players
}

Moulongo Jean Georges André ${ }^{1 *}$, Moussoki Jean Martin ${ }^{1}$, Moussouami Simplice Innoncent ${ }^{1}$, Makosso-Vheiye Georges ${ }^{1}$, Packa Tchissambou Bernard ${ }^{1}$, MASSAMBA Alphonse ${ }^{1}$, Mabiala Babela Jean Robert ${ }^{2}$

${ }^{1}$ Laboratory of Sport Biosciences, Higher Institute of Physical Education and Sports, PO Box 69, Marien NGOUABI University, Brazzaville, Congo ${ }^{2}$ Pediatrics Department, Health Sciences Faculty, PO Box 69, Marien NGOUABI University, Brazzaville, Congo

DOI: $10.36348 /$ jaspe.2020.v03i09.003 | Received: 21.08.2020 | Accepted: 29.08.2020 | Published: 30.09 .2020

*Corresponding author: Moulongo Jean Georges André

Abstract

The aim of this study was to assess and compare blood glucose, lactate and pyruvate concentrations changes during Wingate exercise and $10 \mathrm{~min}$ post-exercise recovery in football players with different aerobic capacity levels. Blood glucose, lactate and pyruvate concentrations were measured in 27 amateur football players during supramaximal Wingate anaerobic test $\left(\mathrm{WA}_{\mathrm{n}} \mathrm{T}\right)$. The subjects were divided into two groups: group1, 16 subjects with maximum oxygen uptake $\left(\mathrm{VO}_{2 \max }\right)$ values whose were higher than $60 \mathrm{ml} / \mathrm{kg} / \mathrm{min}$; group 2, 11 subjects with $\mathrm{VO}_{2 \max }$ values lower than 55 $\mathrm{ml} / \mathrm{kg} / \mathrm{min}$. All subjects performed $\mathrm{WA}_{\mathrm{n}} \mathrm{T}$ after determining the $\mathrm{VO}_{2 \max }$ using an incremental test. The $\mathrm{WA}_{\mathrm{n}} \mathrm{T}$ was performed on an Ergomedic cycle ergometer. Blood samples were collected at rest, at the stop of $\mathrm{WA}_{\mathrm{n}} \mathrm{T}$ and during the 10 minutes' recovery (following $\mathrm{WA}_{\mathrm{n}} \mathrm{T}$ ). Only slight and no significant decrease was observed during $\mathrm{WA}_{\mathrm{n}} \mathrm{T}$ for blood glucose: $5.5 \pm 0.3 \mathrm{mmol} / \mathrm{L}$ vs $4.9 \pm 0.3 \mathrm{mmol} / \mathrm{L}$, group 2 . Very large increases in lactate and pyruvates concentrations were found at the $\mathrm{WA}_{\mathrm{n}} \mathrm{T}$ stop: $12.41 \pm 0.15 \mathrm{mmol} / \mathrm{L}$ vs $1.57 \pm 0.14 \mathrm{mmol} / \mathrm{L}$ for group $1,13.87 \pm 0.12 \mathrm{mmol} / \mathrm{L}$ vs $1.84 \pm 0.25$ $\mathrm{mmol} / \mathrm{L}$ for group 2 . The peaks of [La] were observed at $2 \mathrm{~min}$ post-exercise $\mathrm{WA}_{\mathrm{n}} \mathrm{T}: 12.83 \pm 0.23 \mathrm{mmol} / \mathrm{L}$ and $14.59 \pm 0.32$ $\mathrm{mmol} / \mathrm{L}$ respectively. The same trend was observed for pyruvate concentrations. Blood [La] concentrations measured during 2 min to 10 min recovery decreased significantly, and were significantly and negatively correlated with $\mathrm{VO}_{2 m a w}$. This study clearly confirm that a brief and supramaximal Wingate exercise induced higher lactate and pyruvates concentrations increase in football players with high $\mathrm{VO}_{2 \max }$ level than others with low $\mathrm{VO}_{2 \max }$ level. The major responsible factor is glycolytic capacity.

Keywords: Wingate test, football, blood glucose, lactate, pyruvate, maximal oxygen uptake.

Copyright @ 2020: This is an open-access article distributed under the terms of the Creative Commons Attribution license which permits unrestricted use, distribution, and reproduction in any medium for non-commercial use (NonCommercial, or CC-BY-NC) provided the original author and source are credited.

\section{INTRODUCTION}

Performance in football results from a combination of physiological, psychological, social and environmental factors. Among the physiological factors, aerobic capacity is necessary to maintain performance during the $90 \mathrm{~min}$ of a football match, to undertaken demanding training and to achieve optimal recovery; on the other hand, anaerobic pathways are utilized during very short bursts of moderate to intensive effort that can directly determine a match's outcome [1-3]. The football events have been subject to intense study. The football not only provides the opportunity to study the biochemical changes induced by physical endurance and anaerobic power, but also, uniquely and simultaneously, the possible influence of several variables including training and match situations (sprints, vertical jumps, conquests of ball, ...). Numerous studies of biochemical changes induced by exercise in football players have largerly featured three areas: firstly, changes in glycemia during exercise and recovery period $[4,5]$; secondly, metabolization and release of lactates in response to stress of tissue $[6,7]$; thirdly, pyruvate changes which have been demonstrate in endurance events $[8,9]$.

The majority of these investigations have been laboratory trials, such Wingate $30-\mathrm{s}$ anaerobic test $\left(\mathrm{WA}_{\mathrm{n}} \mathrm{T}\right)$ [10], multistage treadmill testing [12] and submaximal cycle ergometer [11]. However, about valid and reliable laboratory methods of anaerobic power, $\mathrm{WA}_{\mathrm{n}} \mathrm{T}$ has the advantage in that it provides information about both the alactic and lactic anaerobic energy transfer system. The main indices of this test 
are: 1) peak power $\left(\mathrm{P}_{\text {peak }}\right)$, the highest power elicited during the test taken as the average power of any 5-s period; 2) mean power $\left(\mathrm{P}_{\text {mean }}\right)$, the average power during the 30-s test, minimal power; and 3) fatigue index, the difference between $\mathrm{P}_{\text {peak }}$ and minimal power $\left(\mathrm{P}_{\min }\right)$, divided by $\mathrm{P}_{\text {peak }}$. Regarding the taxation of the human energy transfer system during the test, $\mathrm{P}_{\text {peak }}$ is considered as a descriptor of short-term power that relies mainly upon adenosine triphosphate - creatine phosphate (alactic anaerobic system). Previous study on assessing of alactic anaerobic power, conducted on top Congolese team players (volleyball, basketball, football), indicated also a link between $\mathrm{WA}_{\mathrm{n}} \mathrm{T}$ and football performance [13]. In addition, the international literature indicates that during the $\mathrm{WA}_{\mathrm{n}} \mathrm{T}$ lactate concentrations increase notably at the immediate end of the effort continues to increase after 2 minutes postexercise recovery $[14,15]$; these changes, which cannot be modified for glycemia [16], are also noted for pyruvates [9]. However, a difference is observed between lactates and pyruvates, lactates whose dissociation constant is lower diffusing faster than pyruvates [17]. Otherwise, since the studies of Astrand and Rodahl [18] and Astrand [19], maximal oxygen uptake $\left(\mathrm{VO}_{2} \mathrm{max}\right)$ has been considered a good index of the subjects's physical condition. If $\mathrm{VO}_{2 \max }$ would primarly depend on training and sport activity, with genetic factors having a slight effect, we asked ourselves the following questions: what is the stress of the level of aerobic capacity on changes in blood glucose, lactate and pyruvate concentrations during $\mathrm{WA}_{\mathrm{n}} \mathrm{T}$ and during post-recovery exercise in footballers? If the realization of $\mathrm{WA}_{\mathrm{n}} \mathrm{T}$ has an impact on these three biochemical markers of effort, in which footballers (enduring vs less enduring) concentrations decrease the most? The aim of this study was to characterize the levels of glycemia, lactates and pyruvates before and after alactic anaerobic exercise, and during postexercise recovery period $(2,3$, and $5 \mathrm{~min})$. To achieve this objective, we employed supramaximal exercise (Wingate 30-s anaerobic test). Our working hypotheses were that: 1) blood sugar does not vary significantly at the end of $\mathrm{WA}_{\mathrm{n}} \mathrm{T}$, contrary to lactatemia and pyruvicemia; 2) the concentrations of lactates and pyruvates noted decrease markedly after 5 minutes of cessation of exercise compared to that of blood glucose.

\section{METHODS}

This study lies within the scope of a program of evaluation of the physical capacity of the Congolese footballers of first League. All our subjects were not subjected to a dietary and their food did not differ significantly to the fact that they came from social layers whose economic level was medium, as showed Mbemba et al. [20] on a working adult population of Brazzaville.

\section{Participants}

The sample of study was comprised amateur's senior male football players, selected by the probabilistic method and the random choice simple process, among three male teams on the 16 teams involved in competitions of the first division of Brazzaville Football League. Each team comprising a maximal effective of 18 players according to the football match rules of AFC, the study targeted a representative sample of 48 football players. The inclusion criteria of players were: aged 18-30 years old; to hold a sporting validation during the competitive season 2018-2019; to be regular at the training sessions [6 hours at least per week (over 15 hours) and regularly registered the competitions]. Exclusion criteria were: taking antimalarial treatment that could affect blood oxygen transport; taking other drugs that could affect glycemia, lactatemia and pyruvicemia; have $\mathrm{VO}_{2 \max }$ value comprised between $55-60 \mathrm{ml} / \mathrm{kg} / \mathrm{min}$, values which reflect an average aerobic capacity.

In addition, 9 players were excluded in this study for personal or health motivations. A total of 27 football players were included to take part in the study. These subjects were divided into two groups according to the $\mathrm{VO}_{2 \max }$ level: group 1, 16 football players which $\mathrm{VO}_{2 \max }$ higher than $60 \mathrm{ml} / \mathrm{kg} / \mathrm{min}$; group 2, 11 football players which $\mathrm{VO}_{2 \max }$ lower than $55 \mathrm{ml} / \mathrm{kg} / \mathrm{min}$. The mean age was $23.9 \pm 1.8$ years (range: $19-28$ years) [23.6 \pm 2.1 years for group 1 against $24.2 \pm 1.8$ years for group 2]. The protocol was approved by the National Ethics Committee of Health Sciences Research of the Congolese Ministry of Scientific Research, and the study protocol conforms to the ethical guidelines of the 1975 declaration of Helsinki. The football players gave written informed consent after having been explain the procedures, purposes, benefits and possible risks of participation in the study. This study lies within the general scope of the research of optimal performance of African teams in the sub-Saharan environment, project launched by the African Football Confederation (A.F.C).

\section{Experimental protocol}

The subjects were divided into 4 groups of 7 , 7, 7 and 6 during the course of the experiment. For each group, the subjects came to the laboratory on 3 different days (D1, D2 and D3) separated by a period of 2 days. On the first day (d1), the following operations were carried out: a) a medical examination and a resting electrocardiogram in order to eliminate any possible contraindication to exercise tests and to determine the resting heart rate; b) anthropometric measurements; c) an incremental exercise to determine the maximum oxygen consumption. On the second day (d2), the subjects returned to the laboratory to perform a strength / speed test $(\mathrm{F} / \mathrm{V})$ according to the technique described by Vandewalle et al. [11]. Within 48 hours (d3), the subjects performed the Wingate test. This exercise was systematically carried out in the morning, 1 to 2 hours after a standardized breakfast. Everyone was asked to refrain from any strenuous or exhausting training in the previous 24 hours. 


\section{Anthropometric measurements}

Anthropometric measurements were realized: height (measured to $0.5 \mathrm{~cm}$ near) using a portable stadiometer SECA, USA) and weight by using an electronic weight scale (HD-351, Tanita, USA) to the nearest $0.1 \mathrm{~kg}$. From the values of the height and weight, the body mass index (BMI) was calculated according to the Quetelet's formula: BMI = weight $(\mathrm{kg}) /$ height $^{2}(\mathrm{~m})$. The lean body mass (LBM) (in $\mathrm{kg}$ ) was determined using an impedancemeter Omeron BF511 , then this value was translated into kilograms. The bio-impedance measurements were taken by the same operator. These measurements are carried out on each footballer at rest in the lying position. Two surface electrodes are placed on the wrist (radial and ulnar styloid). Two electrodes at the ankle (tibial malleolus) and at the end of the second metatarsal. The data collection focused on total extracellular and intracellular water as well as lean mass by summing the weights of the water compartments by the product of the densities and volumes of each extracellular and intracellular compartment. The choice of this methodological approach in the evaluation of lean mass was based on the study of Pineau and Frey [21].

\section{Aerobic capacity}

Each subject was initially subjected to a progressive test and maximum test in order to determine the maximum oxygen uptake using an indirect calorimetry system (gas analyser Godard, Staham, Holland) with an incremental exercise test to volitional fatigue. The test began with 3-min warm-up at $60 \mathrm{w}$. Pedaling constant speed remained (at 70 rpm) throughout testing, and the load was increased by $30 \mathrm{w}$ every minute until $\mathrm{VO}_{2} \max$ reached. Oxygen uptake $\left(\mathrm{VO}_{2}\right)$ was considered maximal if at least three of the following criteria were met: 1) a respiratory exchange ratio of $>1.10 ; 2$ ) attaintment of age-predicted maximal heart rate $[210-(0.65 \times$ Age $) \pm 10 \%] ; 3)$ an increase in $\mathrm{VO}_{2}$ lower than $100 \mathrm{ml}$ with the last increase in work rate; and 4) an inability to maintain the required pedaling $\mathrm{w}$ frequency $(70 \mathrm{rpm})$ despite maximum exercise and verbal encouragements. A 5-min recovery period was then implemented with $2 \mathrm{~min}$ of pedaling and 3 min of rest.

\section{Anaerobic testing}

The strength / speed test consisted of repeating maximum sprints (less than 10 seconds) on a cycloergometer (Ergomedic 874, Monark, Sweden), the center of gradually increasing braking forces. It made it possible to determine the maximum power $\left(\mathrm{P}_{\text {peak }}\right)$, which was obtained for an optimal load (F) which was that imposed for the realization of the test of Wingate.

To carry out this test, upon arrival at the laboratory, the subject was stretched out for the placement in a vein of the elbow fold of a heparin catheter intended to regularly take blood samples. Before the start of the exercise, he warmed up for 15 minutes at an intensity corresponding to approximately $50 \% \mathrm{VO}_{2 \max }$. $\mathrm{WA}_{\mathrm{n}} \mathrm{T}$ was performed according to the procedure described by Nikolaïdis [22]. It consists of a 30-second supramaximal exercise against the constant braking force $(\mathrm{F})$ previously determined during the F / $\mathrm{V}$ test. The subject was asked to pedal as quickly as possible from the start and to maintain the highest possible pedaling frequency throughout the 30 second period. This test was carried out on the same ergometric bicycle and with the same recording system as the F/ V test.

The exercise tests proceeded between 8 hours and 10 hours in a well aired hall of sports. The average values of temperature and relative humidity of ambient air in situ were respectively $31^{\circ} \mathrm{C}$ and $92 \%$.

\section{Biochemical analysis}

Blood samples were obtained between 8:00 AM and 10: $00 \mathrm{AM}$ after an overnight fast and a day of rest ( 24 hours before $W_{n} T$ ). Fingertip arterialized blood micro samples were taken with a lancet (data base microphone- fine, Becton Dickson) for blood lactate [La] analysis. The biochemical analysis of [La] was performed in a testing strip (BN-Lactate, Roche Diagnoses, Mannheim, Germany), only material available in our laboratory. Assessing of glycemia was used a glucometer Optium XCEED of Abbott with the Penlet scarifier, on blood taken at the end of the finger. The strips came from the Abbott laboratories. Regarding the determination of pyruvate concentrations, blood samples $(10 \mathrm{ml})$ were collected via venous phlebectomy in each participant's upper limb through a cannula. Samples were collected in tubes containing of ethylenediaminetetraacetic (EDTA) and were immediately centrifuged at $4^{\circ} \mathrm{C}$. Plasma samples were kept on dry ice during transportation from the testing site and were stored at $-80^{\circ} \mathrm{C}$ until analyzed. The biochemical analysis of pyruvate [Pyr] were performed in an automated biochemical analyzer using an ILab 300 Plus autoanalyser employing reagents purchased from Biosystems S.A. (Barcelone, Spain), according the manufacturer recommendations. The samples were tested in duplicate with intra-assay coefficients of variation of $4.3 \%$ (glucose), $5.6 \%$ (lactate), and 6\% (pyruvate). These specific parameters were chosen to evaluate the activation of glucose avaibility (glucose), anaeorobic metabolism (lactate) and glycogenolysis and ATP production (pyruvate) related to muscle function [17], and with respect to logistic limitations in measuring parameters.

All samples were taken before and immediately after the 30 seconds of the $\mathrm{WA}_{\mathrm{n}} \mathrm{T}$ test, as well as during post-exercise recovery ( $2 \mathrm{~min}, 5 \mathrm{~min}, 10$ min).

\section{Variables}

The $\mathrm{P}_{\text {peak }}$ powers developed during the $\mathrm{F} / \mathrm{V}$ test and retained in the Wingate test are presented as 
absolute value, relative value per body mass and lean body mass. Blood glucose [Gl], lactate [La] and pyruvates $[\mathrm{Pyr}$ ] concentrations were variables of the study. However, only the lactatemia and the pyruvicemia were followed during the 10 minutes $(2$ $\mathrm{min}, 5 \mathrm{~min}, 10 \mathrm{~min}$ ) of the post-exercise recovery $\mathrm{WA}_{\mathrm{n}} \mathrm{T}$, since these are two biochemical markers which are closely linked at the level of aerobic capacity, glycogenolysis and muscular effort provided during a supramaximal exercise. The associations between [La], [Pyr], and $\mathrm{VO}_{2 \max }$ were analyzed, as well as the variations of [La] and $\left[\mathrm{Pyr}\right.$. Data of $\mathrm{VO}_{2 \max }$ are also presented as absolute value, relative value per body mass and lean body mass. This approach is justified in fact that body composition influences on aerobic capacity, as reported by Bennezidine-Boussaidi and Cazorla [23].

\section{STATISTICAL ANALYSIS}

The results are presented in tabular and graphical form. Shapiro-Wilks tests for normality were conducted, parametric values are reported as means \pm $\mathrm{SD}$. Student's t tests (paired/unpaired) were used to compare two means. However, 2-way analysis of variance (time $\mathrm{x}$ group) was used to compare the dependent variables. In the event of a significant time $\mathrm{x}$ condition interaction, Bonferroni post hoc tests were used to compare the pre-post $\mathrm{WA}_{\mathrm{n}} \mathrm{T}$ of [La] and [Pyr] concentrations. Additionally, a Pearson's two-tailed correlation and linear regression analysis (least squares method) were performed between [La], $\Delta[\mathrm{La}],[\mathrm{Pyr}]$, $\Delta[\mathrm{Pyr}]$ concentrations and the $\mathrm{VO}_{2 \max }$. For all tests, $\mathrm{p}<0.05$ defined the level of statistical significance.

\section{RESULTS}

\section{Anthropometric and maximum oxygen uptake}

The main data of anthropometric characteristics and maximum oxygen uptake are shown in table 1. We note that the two groups were of comparable age, size and weight. The percentage of fat mass of enduring subjects $\left(\mathrm{VO}_{2 \max }<50 \mathrm{ml} / \mathrm{kg} / \mathrm{min}\right)$ was statistically higher than that of enduring patients $\left(\mathrm{VO}_{2 \max }>60 \mathrm{ml} / \mathrm{kg} / \mathrm{min}\right)$; however, lean body mass was significantly lower. The absolute and weightrelated maximum $\mathrm{P}_{\text {peak }}$ powers, developed in the $\mathrm{F} / \mathrm{V}$ event and retained in the $\mathrm{WA}_{\mathrm{n}} \mathrm{T}$ event, were higher in the group of less enduring footballers than that of the enduring.

Table-1: Anthropometric data and anaerobic capacity of subjects

\begin{tabular}{|c|c|c|c|}
\hline & $\begin{array}{c}\text { Whole group } \\
\quad(n=27)\end{array}$ & $\begin{array}{l}\text { Group } 1 \\
(n=16)\end{array}$ & $\begin{array}{c}\text { Group } 2 \\
(n=11)\end{array}$ \\
\hline Age (yrs) & $23.8 \pm 1.9$ & $23.3 \pm 2.5$ & $25.4 \pm 1.3$ \\
\hline Height $(\mathrm{cm})$ & $173.9 \pm 2.3$ & $174.1 \pm 3.1$ & $173.7 \pm 1.5$ \\
\hline Weight (kg) & $68.0 \pm 2.2$ & $69.3 \pm 2.5$ & $66.7 \pm 1.9$ \\
\hline BMI (kg/m2) & $22.5 \pm 1.3$ & $22.9 \pm 1.4$ & $22.1 \pm 1.2$ \\
\hline$\%$ FM & $11.8 \pm 0.9$ & $9.6 \pm 0.6$ & $14.1 \pm 1.2 * *$ \\
\hline LBM (kg) & $61.2 \pm 1.6$ & $63.3 \pm 2.1 *$ & $59.2 \pm 1.2$ \\
\hline $\mathrm{VO}_{2 \max }(\mathrm{ml} / \mathrm{kg} / \mathrm{min})$ & $58.2 \pm 1.4$ & $63.4 \pm 2.3 * * *$ & $53.1 \pm 0.6$ \\
\hline$V_{2} O_{2 \max }(\mathrm{ml} / \mathrm{kgLBM} / \mathrm{min})$ & $58.0 \pm 1.1$ & $63.5 \pm 1.3 * * *$ & $52.5 \pm 0.9$ \\
\hline $\mathrm{VO}_{2 \max }(\mathbf{l} / \mathrm{min})$ & $3.9 \pm 1.2$ & $4.4 \pm 1.7 * *$ & $3.5 \pm 0.8$ \\
\hline $\mathbf{P}_{\text {peak }}(\mathbf{w})$ & $888 \pm 39$ & $825 \pm 33$ & $941 \pm 45$ \\
\hline$P_{\text {peak }}(w / k g)$ & $13.0 \pm 1.3$ & $11.9 \pm 1.4$ & $14.1 \pm 1.2$ \\
\hline$P_{\text {peak }}(w / k g ~ L B M)$ & $14.4 \pm 3.3$ & $13.0 \pm 4.2$ & $15.9 \pm 2.5$ \\
\hline
\end{tabular}

$* \mathrm{p}<0.05$ variables were compared by $\mathrm{t}$ test. $* * \mathrm{p}<0.01$ variables were compared by $\mathrm{t}$ test. $* * * \mathrm{p}<0.001$ variables were compared by $\mathrm{t}$ test.

\section{Biochemical data}

The mean values of glycemia, pyruvicemia and lactatemia at rest and at the stop of the $\mathrm{WA}_{\mathrm{n}} \mathrm{T}$ in all subjects are presented in table 2 . At rest, no difference of blood glucose was found between two groups. A slight drop in blood glucose was observed in enduring and non-enduring footballers: $\Delta=-3.8 \%$ versus $-4.1 \%$. No significant difference was found between the two groups at rest and stopping exercise. Lacatemia increased during the supramaximal exercise. At the end of WAnT, the highest concentrations were found in non-enduring footballers (group 2) and the lowest in enduring (group 1): $13.87 \pm 0.12 \mathrm{mmol} / \mathrm{L}$ versus 12.41 $\pm 0.15 \mathrm{mmol} / \mathrm{L}(\mathrm{p}<0.001)$. With regard to the variations of pyruvicemia in the two groups, the Wingate test resulted in a significant increase in pyruvate concentrations, compared to the values measured at rest, which reached on average at the end of the exercise. $+69.6 \%$ among enduring players and + $71.3 \%$ among non-enduring players. The difference in concentrations between the two groups when $\mathrm{WA}_{\mathrm{n}} \mathrm{T}$ was stopped was also significant $(\mathrm{p}<0.05)$. 
Table-2: Values of glycemia, pyruvicemia and lactatemia before and after anaerobic exercise

\begin{tabular}{|l|c|c|c|}
\hline & At rest & Stop WA $\mathbf{A}_{\mathbf{n}}$ T & P \\
\hline Group 1 (n=16) & & & \\
\hline$[\mathrm{Gl}](\mathrm{mmol} / \mathrm{L})$ & $5.5 \pm 0.3$ & $5.3 \pm 0.3$ & 0.036 \\
\hline$[\mathrm{La}](\mathrm{mmol} / \mathrm{L})$ & $1.57 \pm 0.14$ & $12.41 \pm 0.15$ & 0.001 \\
\hline$[\mathrm{Pyr}](\mu \mathrm{mol} / \mathrm{L})$ & $95.3 \pm 8.7$ & $161.4 \pm 9.8^{\mathrm{b}}$ & 0.021 \\
\hline Group 2 $(\mathbf{n}=11)$ & & & \\
\hline$[\mathrm{Gl}](\mathrm{mmol} / \mathrm{L})$ & $5.1 \pm 0.2$ & $4.9 \pm 0.3$ & 0.044 \\
\hline$[\mathrm{La}](\mathrm{mmol} / \mathrm{L})$ & $1.84 \pm 0.25$ & $13.87 \pm 0.12^{\mathrm{a}}$ & 0.001 \\
\hline$[\mathrm{Pyr}](\mu \mathrm{mol} / \mathrm{L})$ & $109.2 \pm 10.4$ & $187.1 \pm 12.0$ & 0.032 \\
\hline
\end{tabular}

a $\mathrm{p}<0.001$ variables were compared two groups by t test. $\mathrm{b} p<0.05$ variables were compared two groups by $\mathrm{t}$ test.

The variations in lactate and pyruvate concentrations during the 10 minutes of post-supramaximal recovery are illustrated in Figures 1 and 2.

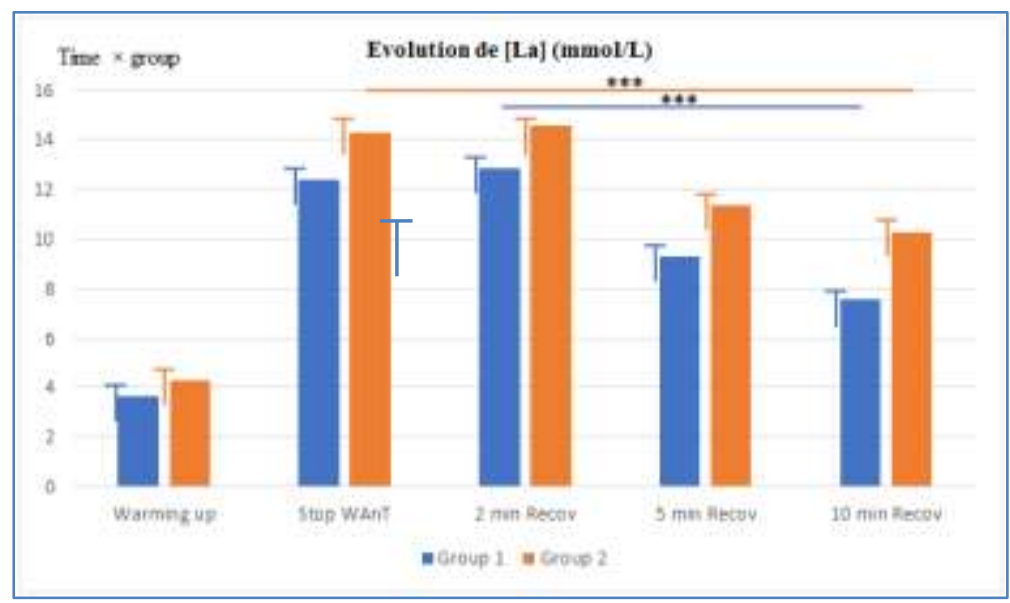

Fig-1: Evolution of [La] concentrations during $10 \mathrm{~min}$ recovery post-exercise $* * * \mathrm{p}<0.001$ variables were compared three and four means by one-way Anova.

Blood lactate concentrations increased significantly during 2 min recovery after $\mathrm{WA}_{\mathrm{n}} \mathrm{T}$ among football players of two groups: $12.83 \pm 0.23 \mathrm{mmol} / \mathrm{L}$ in group $1(\Delta=+3.4 \%)$ versus $14.59 \pm 0.25 \mathrm{mmol} / \mathrm{L}$ in group $2(\Delta=+5.2 \%)$; in 5 at $10 \mathrm{~min}$ recovery, we found respectively: $9.31 \pm 0.24 \mathrm{mmol} / \mathrm{L}$ (group 1) versus $11.35 \pm 0.25 \mathrm{mmol} / \mathrm{L}$. Significant differences were found between subjects in two groups in 2 min to $5 \mathrm{~min}$ recovery: $7.53 \pm 0.32 \mathrm{mmol} / \mathrm{L}$ (group 1) versus $10.25 \pm 0.18 \mathrm{mmol} / \mathrm{L}$ (group 2). A decrease of lactate concentrations was also found from 5 to $10 \mathrm{~min}$ recovery: $\Delta=-23.6 \%$ in group 1 versus $-10.8 \%$ in group 2 .

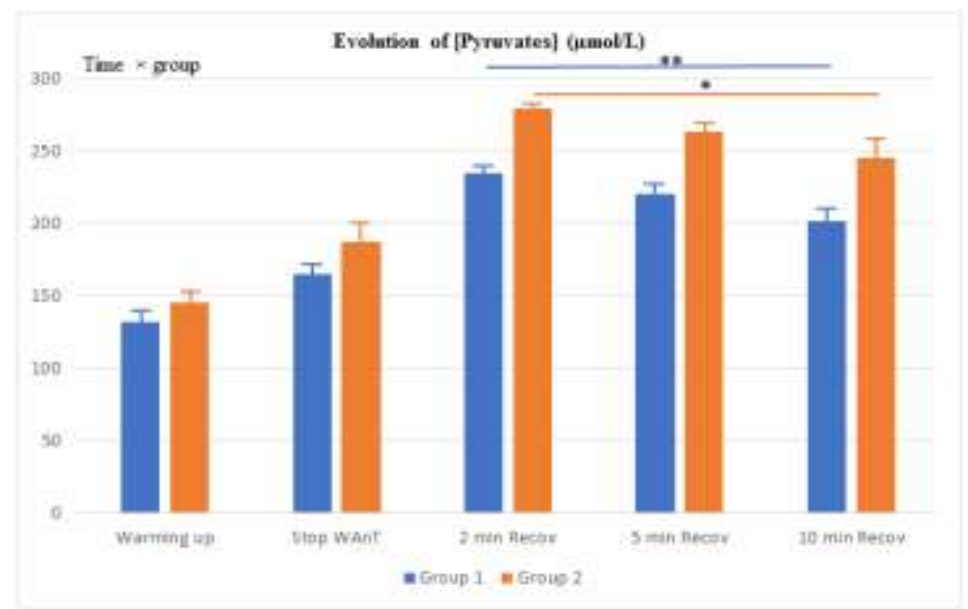

Fig-2: Evolution of pyruvate concentrations during $10 \mathrm{~min}$ recovery post-exercise

$* \mathrm{p}<0.05$ variables were compared three means by one-way Anova. $* * \mathrm{p}<0.01$ variables were compared three means by one-way Anova. 
With regard to pyruvates, concentrations were found higher at the stop $\mathrm{WA}_{\mathrm{n}} \mathrm{T}: 161.4 \pm 9.8 \mu \mathrm{mol} / \mathrm{L}$ for group 1 versus $187.1 \pm 12.0 \mu \mathrm{mol} / \mathrm{L}$ for group 2 . Pyruvates concentrations continue to increase to $2 \mathrm{~min}$ recovery, to reach $234.3 \pm 9.8 \mu \mathrm{mol} / \mathrm{L}$ (group 1) and $278.6 \pm 13.7 \mu \mathrm{mol} / \mathrm{L}$ (group 2). Then, an increase of concentrations was found from 2 to $10 \mathrm{~min}$ recovery, without reaching the basic values.
Finally, the regression analysis (Table 3) shows that in $2 \mathrm{~min}$ to $10 \mathrm{~min}$ recovery, only [La] concentrations were significantly related to $\mathrm{VO} 2 \mathrm{max}$, the binding being negative; the prediction equation is: $[\mathrm{La}]=1.60-0.24 \mathrm{VO}_{2 \max }\left(\mathrm{r}=0.86 ; \sigma_{\mathrm{xy}}=0.71\right)$.

Table-3: Data of regression analysis on $\mathrm{VO}_{2 \max }$

\begin{tabular}{|l|c|c|c|c|}
\hline Variable & $\mathbf{r}$ & $\mathbf{r}^{\mathbf{2}}$ & $\mathbf{f}$ & $\mathbf{P}$ \\
\hline$[\mathbf{L a}]$ & 0.86 & 0.74 & 18.03 & 0.001 \\
\hline$\Delta[\mathbf{L a}]$ & 0.43 & 0.18 & 3.25 & 0.093 \\
\hline$[\mathbf{P y r}]$ & 0.54 & 0.29 & 4.71 & 0.075 \\
\hline$\Delta[\mathbf{P y r}]$ & 0.49 & 0.24 & 4.56 & 0.062 \\
\hline
\end{tabular}

\section{DISCUSSION}

This study shows that a Wingate-type sprint exercise systematically induces an insignificant drop in blood sugar, a significant increase in lactatemia and pyruvicemia in football players up to 2 minutes after $\mathrm{WA}_{\mathrm{n}} \mathrm{T}$ has stopped; the dependent deviations on the level of the aerobic capacity of the subjects, are higher among football players with $\mathrm{VO}_{2 \max }<55 \mathrm{ml} / \mathrm{kg} / \mathrm{min}$. After 2 to 10 minutes of recovery following the $\mathrm{WA}_{n} \mathrm{~T}$ test, a significant decrease of lactate and pyruvate concentrations is observed, the fall being faster among football players with $\mathrm{VO}_{2 \max }>60 \mathrm{ml} / \mathrm{kg} / \mathrm{min}$. What comments suggest the results obtained?

First, our results show that before $\mathrm{WA}_{\mathrm{n}} \mathrm{T}$, after $\mathrm{WA}_{\mathrm{n}} \mathrm{T}$ as during recovery, the values of the glycemia are lower in the football players with $\mathrm{VO}_{2 \max }>60$ $\mathrm{ml} / \mathrm{kg} / \mathrm{min}$ compared to other subjects $\left(\mathrm{VO}_{2 \max }<55\right.$ $\mathrm{ml} / \mathrm{kg} / \mathrm{min}$ ) (Table 2). After $\mathrm{WA}_{\mathrm{n}} \mathrm{T}$, we noted an increase in the glycemia after $\mathrm{WA}_{\mathrm{n}} \mathrm{T}$ in the football players of both groups. This phenomenous would be explained by the increased hepatic production of glucose during the exercise, because of increase in the concentrations of counter-regulation hormones, as described by Duclos [24]. The small increase of glycemia noted in all the football players was also observed in sportsmen in other sports during supramaximal exercise [25]. The absence of modification of the glycemia during a relatively short and not very intense exercise is of current observation; the skeletal striated muscle indeed preferentially uptakes glycogen with glucose during the muscular exercise [24].

Second, with regard to the lactate changes (Figure 1), significant increases in [La] are found at the end of the warm-up and 2 minutes after the $\mathrm{WA}_{\mathrm{n}} \mathrm{T}$ exercise for footballers in both groups. The data obtained suggest that lactate metabolism appears to start earlier in subjects with high aerobic capacity. We can therefore consider that subjects with $\mathrm{VO}_{2 \max }<55 \mathrm{ml} / \mathrm{kg}$ / min have a greater production of lactates whose diffusion is delayed by a lower transport capacity. The peak of [La] observed 2 minutes after the supramaximal exercise disagrees with studies carried out in football players which note it at 5 minutes with similar protocols: $15.12 \pm 0.53 \mathrm{mmol} / \mathrm{L}$ with French professional footballers of comparable age [26], 12.72 $\pm 1.6 \mathrm{mmol} / \mathrm{L}$ 18 -year-old Polish football players in the Dolnoslask League [27]. In addition, our values of lactatemia are similar with those reported by Moussa and al. [7] in professional French football players of $2^{\text {nd }}$ league at the end of $\mathrm{WA}_{\mathrm{n}} \mathrm{T}$ : $13.4 \pm 0.9 \mathrm{mmol} / \mathrm{L}$. However, it should be recalled that the taking away were made in amateur sportsmen. The training factor (content of sessions, volume and intensity of work, climatic conditions, etc.) could undoubtedly be incriminated here, not allowing the glycolitic potential of the muscle of our subjects to be sufficiently developed. It should be emphasized here that the Republic of the Congo occupied $89^{\text {th }}$ FIFA world ranking as of November 2019. However, this hypothesis remains to be verified in subsequent studies.The lower [La] concentrations were found among football players with high $\mathrm{VO}_{2 \max }$ level: $12.83 \pm 0.23 \mathrm{mmol} / \mathrm{L}$ vs $14.59 \pm 0.25 \mathrm{mmol} / \mathrm{L}$. These differences undoubtedly reflect either a lower production of lactates in subjects of group 1 (reduction in lactic debt by an increase in alactic debt), or a more intense metabolism of lactates linked to greater activity. of oxidative metabolism: faster adaptation of the transport system or biochemical adaptation in the striated muscle. In addition, it is shown that the activity of the citrate synthetase is very increased at subjects involved and enduring, from where an increase in the oxidation of lactates, whereas the activity of the LDH decreases reducing the production of lactates [28]. On the other hand, an insufficiency of contribution in oxygen increases the cytoplasmic mitochondriale concentration and of $\mathrm{NADH}^{+}+\mathrm{H}^{+}$which must be oxidized to maintain glycolysis and the ATP production. However, oxidation $\mathrm{NADH}^{+}+\mathrm{H}^{+}$is coupled with the production of lactates starting from the pyruvates. It is in this direction that we observed the significant increase in the pyruvates concentrations after the end $\mathrm{WA}_{\mathrm{n}} \mathrm{T}$ to 2 min post-exercise recovery (Figure 2 ). The lower lactaemia in group 1 can so be explained by both a low glycolytic capacity [29] and by a greater participation of the anaerobic pathway in the supply of 
energy during sprint exercises, as has been demonstrated by the study of Andelkovic et al. [30]. Furthermore, like any anaerobic sprint type test and as reported by Jacobs et al. [15], the Wingate test induces the application in the muscle of by-products resulting from metabolisms involved. The use of ATP and creatine phosphate $(\mathrm{CP})$ leads to the application of phosphorus compounds, purine bases and ammonium. Glycolysis causes large amounts of $\mathrm{H}+$ ions and lactate ions to appear. Studies $[31,32]$ have confirmed that the accumulation of these various metabolites is all the more important as the power developed during $\mathrm{WA}_{\mathrm{n}} \mathrm{T}$ is high, testifying of course to a greater solicitation of the corresponding energy pathways. The powers retained during the $\mathrm{WA}_{\mathrm{n}} \mathrm{T}$ in our study are close to those noted among U-18 Polish football players in the Dolnoslask League [30]: $13.28 \pm 1.43 \mathrm{w} / \mathrm{kg}$ versus $13.0 \pm 1.0 \mathrm{w} / \mathrm{kg}$ in our series. It is therefore probable that the accumulation of lactates is significant in the muscles of football players with $\mathrm{VO}_{2 \max }<55 \mathrm{ml} / \mathrm{kg} / \mathrm{min}$ than those of others, even if no muscle biopsy allows in this study to prove it. Nevertheless, the lactatemia measured at the immediate cessation of $\mathrm{WA}_{\mathrm{n}} \mathrm{T}$ can be considered as a good reflection of the muscular concentration of lactate, since the duration of the test is too short to allow elimination or use of a large quantity of lactate [29]. The significantly higher lactatemia at the end of $\mathrm{WA}_{n} \mathrm{~T}$ in footballers with $\mathrm{VO}_{2 \max }<55 \mathrm{ml} / \mathrm{kg} / \mathrm{min}$ consolidates the hypothesis that the lower the capacity, the higher the muscle concentration of lactates. Third, the pyruvate peaks are observed at 2 min post-recovery: $234.3 \pm 9.8$ $\mu \mathrm{mol} / \mathrm{L}$ in football players with $\mathrm{VO}_{2 \max }>60 \mathrm{ml} / \mathrm{kg} / \mathrm{min}$ vs $278.6 \pm 13.7 \mu \mathrm{mol} / \mathrm{L}$ in other subjects (Figure 2 ). The study by Barthélémy et al., (1981) also reports a peak of pyruvates at 2 min post-exercise in French professional footballers subjected to a $\mathrm{WA}_{\mathrm{n}} \mathrm{T}$ test: $185.0 \pm 9.9 \mu \mathrm{mol} /$ $\mathrm{L}$ at the end of exercise against $244.2 \pm 8.3 \mu \mathrm{mol} / \mathrm{L} 2$ min from recovery, an increase of $+32 \%$. Our data also shown fast decrease of these concentrations during 2 min to $10 \mathrm{~min}$ recovery post- $\mathrm{WA}_{\mathrm{n}} \mathrm{T}$ in football players with $\mathrm{VO}_{2 \max }>60 \mathrm{ml} / \mathrm{kg} / \mathrm{min}$ than other subjects (Figure 2 ), possibly caused by the imbalance between the oxydative and glycolytic capacities of muscle fiber during exercise [27]. One can still consider that the production of blood lactates is related to an increase in the cytoplasmic concentration $\mathrm{NADH}^{+}+\mathrm{H}^{+}$raising the conversion of the pyruvates, as reported by Krustrup and et al. [6].

Fourth, the analysis of regression showed that in $2 \mathrm{~min}$ to $10 \mathrm{~min}$ post-exercise recovery only [La] concentrations decrease significantly and are linked negatively to $\mathrm{VO}_{2 \max }$ (Table 3). A major factor which explains this association is the level of endurance training of subjects. In fact, the endurance training modifies, not only the blood oxygen transport capacity to the muscle, but also the biochemical and energy characteristics of these same muscles [33].

\section{CONCLUSION}

This work made it possible to show, despite some limitations, that the variations in lactate and pyruvate concentrations induced by the Wingate test are more significant and significant in less enduring footballers. The peaks are observed 2 minutes after stopping the submaximal exercise. In addition, a significant decrease is noted from $2 \mathrm{~min}$ to $10 \mathrm{~min}$ from recovery. However, this decrease is faster among footballers with higher aerobic capacity $\left(\mathrm{VO}_{2 \max }>60 \mathrm{ml}\right.$ / $\mathrm{kg} \mathrm{/} \mathrm{min).} \mathrm{Even} \mathrm{if} \mathrm{the} \mathrm{peak} \mathrm{shift} \mathrm{in} \mathrm{lactate}$ concentrations is to be explained in later studies; however, a factor supposedly explaining the variations noted between the footballers of the two groups is an imbalance between the oxidative and glycolitic capacities of the fiber at work, through production, transport capacity and consumption of metabolites.

\section{ACKNOWLEDGEMENTS}

The authors would like to thank the 27 amateur football players from a club in the Congolese first division that participates in national competitions organized by the Congolese Football Federation. The study was approved by the Technical Committee of this Organization.

\section{Disclosure statement}

The authors do not have any financial interest and did not receive any financial benefit from this research.

\section{Conflicts of Interest}

The authors declare no conflicts regarding the publication of this paper.

\section{REFERENCES}

1. Carling, C., Bradley, P., McCall, A., \& Dupont, G. (2016). Match-to match variability in high-speed running activity in a professional soccer team. $J$ Sports Sci, 34(24), 2215-23

2. Di Salvo, V., Gregson, W., Atkinson, G., Tordoff, P., \& Drust, B. (2009). Analysis of high intensity activity in premier league soccer. Int J Sports Med, 30(3), 205-12

3. Rampini, E., Coults, A. J., Costagna, C., Sassi, R., \& Impellizzeri, F. M. (2007). Variation in top level soccer match performance. Int J Sports Med, 28(12): 1018-1024.

4. Manna, I., Khanna, G. L., \& Dhara, P. C. (2010). Effect of training on physiological and biochemical variables of soccer players of different age groups. Asian $J \quad$ Sports Med, 1, 5 https://doi.org/10.5812/asjsm.34875

5. Krzentewski, G., Jandrain, D., \& Pirnay, F. (1984). Avaibility of glucose during exercise. J Appl Physiol Respir Environ Exerc Physiol, 56, 315-320 https://doi.org/10.1152/jappl.1984.56.2.315

6. Krustrup, P., Mohr, M., Steensberg, A., Bencke, J., Kjær, M., \& Bangsbo, J. (2006). Muscle and blood metabolites during a soccer game: implications for 
sprint performance. Medicine and science in sports and exercise, 38(6), 1165-1174.

7. Moussa, E. Z. H., Zouhal, H., Prioux, J., Delamarche, P., \& Gratas-Delamarche. A. (2003). Variations du volume plasmatique induites par un exercice de sprint chez des sprinters, des endurants et des non entraînés de sexe masculin. Sci Q Sports, 18(4), 202-8 https://doi.org/10.1016/S07651597(03)00161-8

8. Thomassen, M., Christensen, P. M., Gunnarsson, T. P., Nybo, L., \& Bangsbo, J. (2010). Effect of 2-wk intensified training and inactivity on muscle $\mathrm{Na}+$ $\mathrm{K}+$ pump expression, phospholemman (FXYD1) phosphorylation, and performance in soccer players. J Appl Physiol, 108(4), 898-905 https://doi.org/10-1123/ijspp.2014-0345

9. Saidi, K., Zouhal, H., Rhibi, F., Tijani, J. M., Boullosa, D., Chebbi, A., \& al. (2019). Effects of six-week period of congested match play on plasma volume variations, hematological parameters, training workload and physical fitness in elite soccer players. PloS ONE, 14(7), e0219692 https://doi.org/10.1371/journal.pone.021 9692

10. Bar-Or, O., \& Skinner, J. S. (1996). Wingate anaerobic test. Human Kinetics: Champaign

11. Vandewalle, H., Peres, G., Heller, J., \& Monod, H. (1985). All out anaerobic capacity tests on cycle ergometers. A comparative study on men and women. Eur J Appl Physiol Occup Physiol, 54(2), 222-229https://doi.org/10.1007/0BF 02335934

12. Baumgartner, T., \& Jackson, S. (1995). Measurement for evaluation in physical education and exercise science. Dubuque: Wn. C. Brown Communications Inc

13. Bongbele, J., Massamba, A., Mboussa, A., \& Kiori, R. (1999). Influence du test d'évaluation sur la puissance anaérobie maximale chez les joueurs d'élite mélano-africains. STAPS, 4, 99-106

14. Berthoin, S., Pelayo, P., Baquet, G., Marais, G., \& Robin, H. (2000). Effets des variations du volume plasmatique sur les concentrations de lactate et leur cinétique de récupération après des exercices maximaux et supramaximaux. Sci \& Sports, 15, 3139

15. Jacobs, T., Tesch, P. A., Bar-Or, O., Karlson, J., \& Dotran, R. (1983). Lactate in human skeletal muscle after 10 s and 30 s of supramaximal exercise. $\begin{array}{llll}J & \text { Appl } & \text { Physiol, } & 5,\end{array}$ https://doi.org/10.1152/jappl.1983.55.2.365

16. Moussa, E., Zouhal, H., Vincent, S., Prioux, J., Delamarche, P., \& Gratas-Delamarche, A. (2003). Effect of sprint duration (6s or 30s) on plasma glucose regulation in untrained male subjects. $J$ Sports Med Phys Fitness, 4, 546-53

17. Banfi, G., Colombini, A., Lombardi, G., \& Lubbowska, A. (2012). Metabolic markers in sports medicine. Adv Clin Chem, 56, 1-54 https://doi.org/10.1016/b978-0-12-3943170.00015-7
18. Astrand, P. O., \& Ryhming, I. (1954). A nomogram for calculation of aerobic capacity (physical fitness) from pulse rate during submaximal work. $J$ Appl Physiol, 7, 218-221

19. Astrand, L. (1980). Aerobic power capacity in men and women with special reference to age. Acta Physiol Scand, 40(Suppl.), 160

20. Mbemba, F., Bantsimba, M., Massamba, A., \& Senga, P. (2005). Alimentation d'une population adulte active à Brazzaville (Congo). Médecine \& Nutrition, 41, 183-188 https://doi.org/101051/mnut/2005.414183

21. Pineau, J. C., \& Frey, A. (2014). Comparaison de la composition corporelle obtenue par bioimpédance et par absorptiométrie biphotonique chez des sportifs de haut niveau. Science \& Sports, 29 ,

164-167

https://doi.org/10.1016/j.scispo.2014.03.001

22. Nikolaïdis, P. T. (2011). Anaerobic power accross adolescence in soccer players. Human Movement, 12(4), 342-347 https://doi.org/10.2478/v10038011-0039-1

23. Bennezidine-Boussaidi, L., \& Cazorla, G. (2008). Aspects biologiques des interactions de l'exercice et de la récupération. Science \& Sports, 23, 6-15.

24. Duclos, M. (2001). Effets de l'entraînement physique sur les fonctions endocrines. Ann Endocrinol, 62(1), 19-32 https://doi.org/AE-022001-62-1-C1-0003-4266-101019-ART2

25. Lippi, G., Brocco, G., Franchini, M., Schena, F., \& Guidi, G. (2004). Comparison of serum creatine, uric acid, albumin and glucose in male professional endurance athletes compared with healthy controls. Clin Chem Lab Med, 42, 6447 https://doi.org/10.1515/CCLM.2004.110

26. Barthélémy, L., Bardou, L., Michaud, A., \& Courgeon, M. (1981). Variations de la glycémie, de la lactatémie et de la pyruvicémie au cours de l'effort. Applications à la surveillance d'une équipe de footballeurs professionnels. Médecine du Sport, 55(2), 146-152

27. Polczyk, M., \& Zaton, M. (2015). Effects of glycolytic-based interval training on anaerobic capacity in soccer players. Human Movement, 16(3), 149-162 https://doi.org/10.1515/humo2015-0041

28. Silva, A. S. T., Santhiago, V., Papeti, M., \& Gobano, C. A. (2008). Haematological parameters and anaerobic threshold in Brazilian soccer players throughout a training program. Int J Lab Hematol, 30, 158-66 https://doi.org/10.1111/j.1751553X.2007.00919.X

29. Therminarias, A. (1993). Catécholamines et production de lactate musculaire. Science \& sports, 8(3), 163-166.

30. Anđelković, M., Baralić, I., Đorđević, B., Stevuljević, J. K., Radivojević, N., Dikić, N., ... \& Stojković, M. (2015). Hematological and biochemical parameters in elite soccer players 
during a competitive half season. Journal of medical biochemistry, 34(4), 460-466.

31. Favier, R. J., Constable, S. H., Chem, N., \& Holloszy, J. O. (1986). Endurance exercise training reduces lactate production. J Appl Physiol, 61(3), 885-9 https://doi.org/10.2478/jomb-2014-0057

32. Lormes, W., Lehman, M., \& Steinacker, J. M. (1998). The problem to study plasma lactate. Int J Sports Med, 19(3), 223-5 https://doi.org/10.1055/s2007-971909
33. Helgerud, J., Engen, L. C., Wisloff, U., \& Hoff, J. (2001). Aerobic endurance improves soccer performance. Med Sci Sports Exerc, 33, 1925-1931 https://doi.org/10.1097/00005768-20011100000019

34. FIF/Coca-Cola World Ranking. (2019). Avaible at: www.fr.n,wikipedia.org. Access date: December 16. 